\title{
Endoscopic laser therapy in malignant tracheobronchial obstruction using sequential Nd YAG laser and photodynamic therapy
}

\author{
K Moghissi, K Dixon, E Hudson, M Stringer, S Brown
}

\begin{abstract}
Background - Because the survival after treatment of advanced inoperable endotracheobronchial carcinoma is so poor, a pilot study was undertaken to evaluate the combined cumulative effect on survival of neodymium yttrium aluminium garnet (Nd YAG) laser followed by photodynamic treatment used endoscopically.

Methods - Seventeen patients who presented between January 1992 and March 1996 with inoperable tracheobronchial lesions causing more than $\mathbf{5 0 \%}$ endoluminal obstruction were selected to enter the pilot study. Initially they had bronchoscopic Nd YAG laser treatment to debulk the tumour, and this was followed six weeks later by photodynamic therapy to treat the residual tumour.

Results - All patients had symptomatic relief and at least a partial response, and seven had a complete response for 3-6 months. Eight of the 17 (47\%) survived for at least two years and $11(65 \%)$ survived for a year or more. The median survival of the 10 patients who had died by the time of writing was 18.5 months (range 5-39), 95\% confidence interval (CI) 9.9 to 29.5 . Conclusions - Combined Nd YAG laser and endoscopic photodynamic therapy may be an effective palliative treatment for patients with inoperable endotracheobronchial cancer.
\end{abstract}

(Thorax 1997;52:281-283)

Keywords: malignant airway obstruction, endotracheobronchial cancer, Nd YAG laser, photodynamic therapy.

The reported survival of patients with advanced, inoperable, obstructing endotracheobronchial carcinoma ranges from one to 48 weeks when treated with neodymium yttrium aluminium garnet (Nd YAG) laser. ${ }^{1}$ The YAG laser is widely used endoscopically to treat such lesions $\mathrm{s}^{2-5}$ and in recent years photodynamic therapy has been shown to achieve similar or even better results ${ }^{6-8}$ with complete local clearance of superficial tumours. ${ }^{910}$ Experience indicates that, whereas the YAG laser will instantly evaporate bulky obstructing tumours, the effects of photodynamic therapy are slower but seem to be more long lasting and its delivery into smaller bronchi is both easier and safer. ${ }^{11}$

We report our preliminary experience with combining both types of laser treatment in selected patients with malignant intraluminal tracheobronchial lesions.

\section{Methods}

Patients with an established diagnosis of inoperable primary or secondary tracheobronchial carcinoma and more than $50 \%$ intraluminal obstruction who presented between January 1992 and March 1996 were selected to enter the study.

On admission each patient underwent full clinical, laboratory, and radiological investigations which included the clinician's personal assessment of the patient's general condition which was described as "good", "fair", or "poor", the World Health Organisation (WHO) performance status (table 1), and measurement of forced vital capacity (FVC) and forced expiratory volume in one second $\left(\mathrm{FEV}_{1}\right)$. Patients then underwent tracheobronchoscopy so that the site and extent of the tumour could be assessed, a biopsy specimen was taken for histological examination, and the degree of luminal obstruction (expressed as a percentage of the total) was recorded.

PROTOCOL FOR LASER TREATMENT

Details of both techniques have been reported elsewhere. ${ }^{112}$ All treatments were undertaken under general anaesthesia.

For YAG laser treatment the delivery fibre was introduced through the channel of the Moghissi-Jessop bronchoscope ${ }^{13}$ using pulses of $40-60 \mathrm{~W}$ for four seconds in non-contact mode. This treatment was given first to debulk the tumours of the trachea or main bronchi.

Photodynamic therapy was given 4-6 weeks later. Patients were intravenously injected with polyhaematoporphyrin, $2 \mathrm{mg} / \mathrm{kg}$ body weight, and 24-48 hours later they received photodynamic therapy with illumination by $630 \mathrm{~nm}$ light generated by a copper vapour (Oxford) laser. Light was delivered through a $400 \mu \mathrm{m}$ optical fibre with a cylindrical end diffuser $0.5-2 \mathrm{~cm}(400 \mathrm{~mW} / \mathrm{cm}$ of diffuser $)$ which was passed through the biopsy channel of the fibreoptic bronchoscope that had been introduced into a rigid bronchoscope. Each treatment lasted for 20-30 minutes.

Patients were usually treated as day cases except, rarely, for social reasons. They were

Table 1 World Health Organisation (WHO) performance status

0 Normal activity without restriction

1 Strenuous activity restricted, can do light work

2 Up and about $>50 \%$ of waking hours, capable of self-care

3 Confined to bed $>50 \%$ of waking hours, limited self-care

4 Confined to bed or chair, no self-care, completely disabled.
23 October 1996

Accepted for publication

30 October 1996 
Table 2 Details of patients before laser treatment

\begin{tabular}{|c|c|c|c|c|c|c|}
\hline $\begin{array}{l}\text { Case } \\
\text { no. }\end{array}$ & $\begin{array}{l}\text { Age } \\
\text { (years) }\end{array}$ & Sex & $\begin{array}{l}\text { Histological type } \\
\text { of carcinoma }\end{array}$ & Previous treatment & Site of tumour & $\begin{array}{l}\text { General } \\
\text { condition }\end{array}$ \\
\hline 1 & 69 & $M$ & Adenoid cystic & Radiotherapy & Tracheal bifurcation & Good \\
\hline 2 & 79 & $\mathrm{~F}$ & Squamous & Operation & Tracheal bifurcation & Good \\
\hline 3 & 71 & $\mathrm{~F}$ & Adeno & None & Left main bronchus & Good \\
\hline 4 & 61 & M & Secondary (renal) & Operation & Left main bronchus & Good \\
\hline 5 & 65 & $\mathrm{~F}$ & Squamous & Operation + radiotherapy & Left main bronchus & Fair \\
\hline 6 & 75 & $\mathrm{~F}$ & Squamous & Operation & Tracheal bifurcation & Poor \\
\hline 7 & 78 & M & Squamous & Operation & Left lower lobe & Fair \\
\hline 8 & 79 & $\mathrm{~F}$ & Large cell & Radiotherapy & Left main bronchus + lower lobe & Poor \\
\hline 9 & 79 & M & Squamous & Operation & Right main bronchus & Fair \\
\hline 10 & 64 & $M$ & Small cell & Chemotherapy & Right intermediate bronchus & Good \\
\hline 11 & 71 & $M$ & Squamous & Radiotherapy & Tracheal bifurcation & Poor \\
\hline 12 & 69 & $\mathrm{~F}$ & Squamous & Radiotherapy & Left main bronchus & Poor \\
\hline 13 & 73 & $\mathrm{~F}$ & $\begin{array}{l}\text { Adeno } \\
\text { ade }\end{array}$ & Radiotherapy & Right main bronchus & Poor \\
\hline 14 & 45 & $\mathrm{~F}$ & Adeno & Chemotherapy & Left lower lobe & Good \\
\hline 15 & 63 & $\mathrm{M}$ & Adeno & Operation + radiotherapy & Right intermediate bronchus & Good \\
\hline 16 & 63 & $M$ & Adeno & Operation + radiotherapy & Right main bronchus & Good \\
\hline 17 & 62 & $M$ & Squamous & Chemotherapy & Right main bronchus & Fair \\
\hline
\end{tabular}

recalled 5-7 days later for bronchoscopic examination, debridement, or further treatment to deal with any remaining remnants of tumour. Each patient had a further bronchoscopic examination after 5-6 weeks for reassessment of the degree of opening of the bronchial lumen and to obtain biopsy specimens and retreat if required.

All patients were followed up in the outpatient clinic every $6-8$ weeks when they were examined clinically and radiologically and their performance status and pulmonary function were reassessed and recorded. Every three months (or earlier if indicated) they had a bronchoscopy, the degree of luminal opening was assessed, biopsy specimens were obtained, and any retreatment planned. These follow up visits continued until the patient died.

Results were recorded after one treatment cycle comprising YAG laser followed by photodynamic therapy had been completed. Relief of symptoms, WHO performance score, and the patient's subjective degree of satisfaction were recorded on a simple questionnaire. Pulmonary (ventilation) function, changes in the chest radiograph, percentage bronchial luminal opening, and pathological response to treatment were also recorded.

Complete response to treatment was defined as macroscopic and microscopic absence of tumour at endoscopic examination, and partial response as a more than $50 \%$ reduction in the bulk or extent of the endoluminal tumour.

\section{Results}

Seventeen patients (nine men) of mean (SD) age 69 (9) years (range 45-79) were admitted to the study. They all had inoperable or unresectable tumours, clinical stage IIIa or IIIb (T3N2 or T4N1). Further pretreatment data are shown in table 2. Sixteen patients had primary bronchopulmonary cancers and one had a secondary tumour. The overall degree of intraluminal tracheobronchial obstruction ranged from $60 \%$ to $100 \%$.

Detailed results are shown in table 3 . There were no procedure-related deaths and only one patient developed a mild photosensitivity reaction. All patients had their symptoms palliated and all were subjectively satisfied with their treatment. The mean improvements in FVC and $\mathrm{FEV}_{1}$ were $28 \%$ (range 0-90\%) and $25 \%$ (range $0-70 \%$ ), respectively. This was matched by improvement in performance status and a mean percentage increase in luminal opening of $66 \%$ (range $40-90 \%$ ). The pathological response was complete in seven patients for a period of 3-6 months. One patient with adenoid cystic carcinoma remained in complete remission for two years and died after 39 months of a bladder cancer of different histological type.

Eleven of the 17 patients (65\%) survived for one year and eight $(47 \%)$ for two years. The median survival of the 10 patients who had died by the time of writing was 18.5 months (range 5-39), 95\% CI 9.9 to 29.5. The survival curve for the entire series is shown in fig 1.

Table 3 Results of sequential treatment with Nd YAG laser and photodynamic therapy

\begin{tabular}{|c|c|c|c|c|c|c|}
\hline \multirow{3}{*}{$\begin{array}{l}\text { Case } \\
\text { no. }\end{array}$} & \multicolumn{2}{|c|}{$\begin{array}{l}\text { Actual (\%) increase in } \\
\text { pulmonary function }(\mathrm{ml})\end{array}$} & \multirow{3}{*}{$\begin{array}{l}\text { Percentage change } \\
\text { in luminal opening }\end{array}$} & \multirow{3}{*}{$\begin{array}{l}\text { Outcome } \\
\text { (months) }\end{array}$} & \multicolumn{2}{|c|}{ WHO performance status } \\
\hline & & & & & \multirow{2}{*}{$\begin{array}{l}\text { Before } \\
\text { treatment }\end{array}$} & \multirow{2}{*}{$\begin{array}{l}\text { After } \\
\text { treatment }\end{array}$} \\
\hline & $F V C$ & $F E V_{1}$ & & & & \\
\hline 1 & $920(25)$ & $420(13)$ & 70 & Died (39) & 2 & 0 \\
\hline 2 & $620(42)$ & $100(10)$ & 80 & Died (25) & 3 & 1 \\
\hline 3 & $610(35)$ & $600(47)$ & 60 & Alive (37) & 2 & 0 \\
\hline 4 & $440(10)$ & $220(7)$ & 80 & Alive (52) & 2 & 0 \\
\hline 5 & $600(32)$ & $220(15)$ & 90 & Died (26) & 3 & 1 \\
\hline 6 & $270(33)$ & $140(20)$ & 80 & Died (5) & 3 & 1 \\
\hline 7 & $520(30)$ & $420(30)$ & 40 & Alive (24) & 2 & 0 \\
\hline 8 & $720(90)$ & $330(40)$ & 90 & Died (5) & 2 & 1 \\
\hline 9 & $350(22)$ & $100(10)$ & 70 & Died (35) & 2 & 1 \\
\hline 10 & $200(10)$ & $580(40)$ & 60 & Died (35) & 2 & 0 \\
\hline 11 & $230(17)$ & $130(17)$ & 60 & Died (9) & 2 & 1 \\
\hline 12 & 0 & 0 & 40 & Died (6) & 3 & 2 \\
\hline 13 & $290(30)$ & $480(70)$ & 50 & Died (12) & 2 & 1 \\
\hline 14 & $115(5)$ & $80(5)$ & 50 & Alive (12) & 2 & 1 \\
\hline 15 & $1020(40)$ & $890(40)$ & 80 & Alive (10) & 2 & 1 \\
\hline 16 & $790(30)$ & $700(35)$ & 70 & Alive (10) & 2 & 0 \\
\hline 17 & $300(20)$ & $150(20)$ & 45 & Alive (12) & 2 & 1 \\
\hline
\end{tabular}

$\mathrm{FVC}=$ forced vital capacity $\mathrm{FEV}_{1}=$ forced expiratory volume in one second.

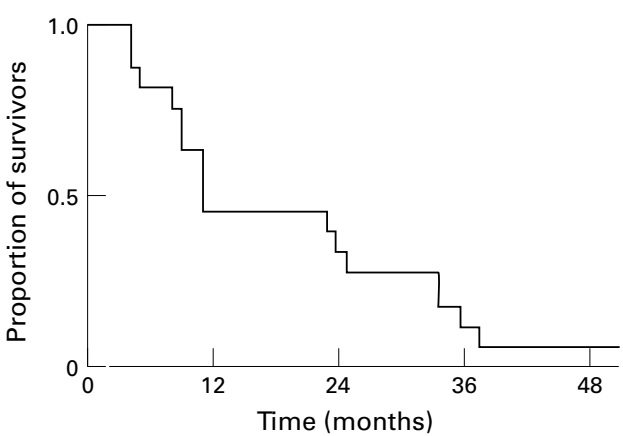

Figure 1 Survival curve for all the 17 patients in the series. 


\section{Discussion}

At most, $20 \%$ of all patients with lung cancer are referred for or undergo resection of their tumours. ${ }^{14}$ External beam radiotherapy or chemotherapy, or both, have commonly been used to treat unresectable tumours. More recently Nd YAG laser treatment has been shown to give good relief of symptoms in patients with appreciable endoluminal obstruction, but it has both limitations and drawbacks that emanate from the fact that light is emitted from the end of its delivery fibre in a straight line. However, the second and third generation bronchial divisions are not in line with the main stem or the lobar bronchial openings so, while the proximal part of the obstructing tumour can be evaporated, its distal portion (within a bronchial subdivision) may not be safely irradiated. This may account for some of the reported complications of bronchoscopic YAG laser treatment. ${ }^{131617}$

Experience in bronchoscopic photodynamic therapy ${ }^{11}$ and its comparison with YAG laser treatment indicates that the bronchial disobliteration achieved with photodynamic therapy is equally good but has a longer lasting effect. Also, it may be applied precisely to small segmental (and even subsegmental) tumours.

It is important to emphasise that the effect of these two lasers is not competitive but complementary. Logically, therefore, there is a definite advantage in using them in sequence for some cases of obstructive bronchial cancer to achieve optimum results.

In addition to relief of symptoms and improved pulmonary function, our results demonstrate improved survival with $47 \%$ of patients surviving two years and $65 \%$ surviving one year. The median survival of the 10 patients who had died by the time of writing was 18.5 months. This is an improvement over the reported survival of patients treated with either bronchoscopic YAG laser or photodynamic therapy alone, although few accurate data are available. Hetzel and Smith ${ }^{5}$ reviewed 19 publications from worldwide sources involving 2000 patients in whom YAG laser had been used for predominantly malignant tracheobronchial lesions. In the largest series in this study, ${ }^{1}$ which included 1310 patients, one year survival was $25 \%$; in most other series it varied from one to 48 weeks. McCaughan et $a l^{8}$ reported a series of 31 patients treated by photodynamic therapy alone (one of the largest series). Their longest survivor died at 34 months. Our results also compare favourably with the overall results of treatment of lung cancer by other methods at a similar stage of the disease. ${ }^{151819}$

The clinical outcome and pathological response to treatment in our patients seems to indicate that in some cases we were able to eradicate local disease completely. This suggests that combined treatment of bulky endoluminal tracheobronchial tumours can achieve a local response similar to that obtained by using photodynamic therapy in early cancer. ${ }^{9}$
An example of an ideal patient to be treated in this way is case 1 with adenoid cystic carcinoma limited to the lower trachea, carina, and both bronchi. He had a complete response for 18 months and eventually died of a second primary cancer (in the bladder) of different histological type.

There is also a case to be made for combination laser treatment as an adjunct to chemotherapy and radiotherapy for patients with endoluminal tumours and advanced mediastinal extraluminal and lymphatic spread. The chemotherapy and radiotherapy will target the mediastinal and nodal disease while the lasers will destroy the endoluminal lesion.

We conclude that patients who, despite their inoperable malignant and tracheobronchial obstruction (irrespective of histological type), are in reasonably good general condition may well benefit from combined treatment with the YAG laser and photodynamic therapy used sequentially. Previous chemotherapy is not a contraindication and, indeed, may even be helpful in treating coexisting mediastinal disease.

We thank the Yorkshire Cancer Research Campaign and The Laser Trust (Moghissi) Appeal for supporting this work.

1 Personne C, Colchen A, Leroy M, Vourch G, Toty L. Indication and technique for YAG laser resection in bronchology, a critical analysis based on 2285 resections. 7 Thorac Cardiovasc Surg 1986;91:710-5.

2 Toty L, Personne C, Colchen A, Vourc H. Bronchoscopic management of tracheal lesions using the Nd YAG laser. Thorax 1981;36:175-8.

3 Dumon JF, Reboud E, Garbe L, Aucompte F, Meric B. Treatment of tracheo-bronchial tumours by laser photoresection. Chest 1982;81:278-84.

4 Unger M. Bronchoscopic utilization of the Nd YAG laser for obstructing lesions of the trachea and bronchi. Surg Clin North Am 1984;64:931-8.

5 Hetzel MR, Smith SGT. Endoscopic palliation of tracheobronchial malignancies. Thorax 1991;46:325-33.

6 Vincent R, Dougherty T. Photoradiation therapy in the treatment of advanced carcinoma of the trachea and bronchus. Proc Clin Biol Res 1984;170:759-66.

7 Balchum OJ, Doiron Dr, Hutch GC. Photoradiation therapy of endobronchial lung cancer employing the photodynamic action of haematoporphyrin derivative. Laser Surg Med 1984;4:13-30.

8 McCaughan JS Jnr, Hawley PC, Bethel BH, Walker J. Photodynamic therapy of endobronchial malignancies. Cancer 1988;62:691-701.

9 Hayata Y, Kato H, Konaka C, Amemiya R, Ono J, Ogwa $\mathrm{I}$, et al. Photoradiation therapy with haematoporphyrin derivative in early and stage I lung cancer. Chest $1984 ; 86$ : 169-77.

10 Okunaka T, Kato H, Konaka C. A clinical trial of photodynamic therapy for early stage lung cancer. Int photodynamic therapy fo

11 Moghissi K, Dixon K, Parsons RJ. A controlled trial of Nd YAG laser vs photodynamic therapy for advanced malignant bronchial obstruction. Lasers Med Sci 1993;8: 269-73.

12 Moghissi K, Parsons RJ, Dixon K. Photodynamic therapy (PDT) for bronchial carcinoma with the use of rigid bronchoscope. Lasers Med Sci 1991;7:381-5.

13 Moghissi K, Jessop T, Dench M. A new bronchoscopy set for laser therapy. Thorax 1986;41:485-6.

14 Whitehouse JMA. Management of lung cancer. Report of Working Group. Current Clinical Practices 1994:1.

15 Joslin C, Rider L, eds. Cancer in Yorkshire. Cancer Registry

Special Report Series 1: Lung cancer. 1994:21-2.
16 Cavaliere S, Foccoli P, Farina P. Nd YAG laser bronchoscopy: a five year experience with 1396 applications in 1000 patients. Chest $1988 ; 94: 15-21$.

17 Spasova I, Patek J, Fiser F, Opalka P. Management of tracheobronchial malignant lesions with Nd YAG laser. Experience with 276 applications in 80 patients. In: Motta $\mathrm{G}$, Grafica LP, eds. Lung cancer frontiers in science and $\mathrm{G}$, Grafica LP, eds. Lung cancer frontiers in science and
treatment (Proceedings of international meeting) Genoa, 1993: 343-8.

18 Darteville P, Macchiarini P, Chapelier A. Resection for T3/ 4 non-small cell lung cancer. In: Motta G, Grafica LP, eds. Lung cancer frontiers in science and treatment (Proceedings of international meeting) Genoa, 1993:449-58.

19 Sabanathan S, Richardson J, Mearns AJ, Goulden C. Results of surgical treatment of stage III lung cancer. Eur F Car diothorac Surg 1994;8:183-7. 